\title{
Surfactant Protein A Binds to the Major Surface Glycoproteins of Pneumocystis carinii via the Carbohydrate Recognition Domain
}

\author{
SP-Aはニューモシスティスカリニの主要表面糖タンパク質に \\ CRDを介して結合する
}

Key words : AIDS, carbohydrate recognition domain, lecin, Pneumocystis carinii, SP-A

Pulmonary surfactant protein A (SP-A) is an alveolar glycoprotein containing four distinct structural segments : (1) a short $\mathrm{N}$-terminal globlar region, (2) a collagen-like domain of proline-and hydroxyproline-rich Gly-X-Y repeats, (3) a hydrophobic "neck" region and (4) a calcium-dependent carbohydrate recognition domain (CRD) which is extensively conserved in several mammalian lectins. SP-A has been shown to bind to the surface of bacterial, viral, and fungal organims and enhances microbial adherence and phagocytosis by macrophages. SP-A also binds to Pneumocysis carinii which is most closely related to the fungi. The binding of SP-A to $P$. Carinii is mediated by the major surface glycoproteins (MSGs) composed of proteins having a broad molecular range at $116 \mathrm{kDa}$, and a minor protein of $80 \mathrm{kDa}$. MSGs bear N-linked carbohydrate chains, and the calcium-dependent interaction of SP-A with MSGs is inhibited by mannosylated albumin and methyl- $\alpha$ mannoside [Zimmerman, P.E., Voelker, D.R., McCormack, F.X., Palsrud, J.R., and Martin, W.R., (1992) J. Clin. Invest. 89, 143-149], suggesting that SP-A recognizes the carbohydrate moiety of MSGs of $P$. carinii via the CRD. Direct evidence that the CRD of SP-A is responsible for the binding to oligosaccharides attached to MSGs had not been shown, but recently McCormack et al. isolated native rat SP-A and prepared several recombinant rat SP-As having mutations within the amino acid sequence of the CRD in a bacurovirus sistem and examined the binding acivity to MSGs [McCormack, F.X., Festa, A.L., Andrews, R.P., Linke, M., and Walzer, P.D., (1997) Biochemistry 36, 8092-8099]. Native SP-A binds to both whole $P$. carinii and purifide MSGs immobilized on plastic titer plate. The binding of SP-A was decresed by deglycosylation of MSGs, and either mannose or galactose inhibited the binding competitively. The candidate amino acid residues involved in the carbohydrate binding of SP-A (Glu195, Arg197, Glu202, Asn214, and Asp215) were chosen on the basis of the crystal structure of mannose-binding protein $\mathrm{A}$, that is homologous to SP-A, complexed with an oligosaccharide [Drickamer, K. (1992) Nature 360, 183-186, and Weis, W.-I., Drickamer, K., and Hendrickson, W.A., (1992) Nature 360, 127-134]. Based on the results obtained from the binding to mannose-Sepharose and MSGs, Glu195, Glu202, Asn214, and Asp215 are important for the binding of SP-A to carbohydrate while Arg197 does not ap-
肺サーファクタントプロテインA (SP-A) は肺胞上皮細胞 より産生される糖タンパク質で、構造上4つの機能ドメイン (1) $\mathrm{N}$ 末ドメイン、(2) プロリンおよび八イドロキシプロリンに富 むコラーゲン様ドメイン、(3) 疎水的な “ネック”領域、そし て (4) C タイブレクチンに共通するカルシウム依存的な糖認識 ドメイン（CRD）から成る。SP-A は細菌・ウィルス・真菌類に 結合し、マクロクファージの微生物への接着、食作用を促進し、 ニューモシスティスカリニにもその主要表層糖タンパク質 (MSGs, 116kDa および80kda) を介して結合する。MSGsはN 結 合型糖鎖を持ち、カルシウム依存的な SP-A と MSGsの相互作用 はマンノシルアルブミン、メチル $\alpha$ マンノシドにより阻害され ることから [Zimmerman, P.E., Voelker, D.R., McCormack, F.X., palsrud, J.R., and Martin, W.R., (1992) J. Clin. Invest. 89, 143-149]、 SP-A の CRD がMSGsの糖鎖を認識して結合することが示唆さ れてきた。これまでSP-A のCRDがMSGsの糖鎖と結合する直 接的な証拠は示されていなかったが、最近McCormackらは野生 型ラット SP-A および CRD 領域に変異を入れた SP-A を使って SP-Aがニューモシスティスカリニ表面の MSGsにCRDを介し て結合することを示した [McCormack, F.X., Festa, A.L., Andrews, R.P., Linke, M., and Walzer, P.D., (1997) Biochemistry 36, 8092-8099]。McCormackらの論文の要約を以下に紹介する。 野生型 SP-A はニューモシスティスカリニの菌体および精製 MSGsに結合し、SP-Aの結合はMSGsを脱グリコシル化するこ とにより減少し、マンノースおよびガラクトースにより阻害さ れた。マンノース結合タンパク質 $\mathrm{A} の$ 結晶構造解析の結果 [Drickamer, K. (1992) Nature 360, 183-186, and Weis, W.I., Drickamer, K., and Hendrickson, W.A. (1992) Nature 360, 127-134] をもとにSP-A の糖結合活性に関与寸ると考えられる CRD内の アミノ酸残基を選択し、調製した変異体の結合性を比較したと ころ、Glu195、Glu202、Asn214、Asp215がSP-A と糖鎖との結 合には重要で、一方、Arg197は結合にはあまり関与しないこと 
pear to play a major role. Asn214 and Asp215 are located in the motif of Trp-Asn-Asp which is present in the most of the reported C-type lectins. Mutant SP-As substituted in these reisdues lack carbohydrate binding activity, indicating the importance of Trp-Asn-Asp motif for carbohydrate recognition. SP-A has two potential N-linked carbohydrate attachment sequences. In previous studies the $\mathrm{N}$-linked carbohydrate chains were shown to be recognized by viruses. However, the deletion mutants of the oligosaccharide attachment domains of SP-A had little or no alteration in the binding to MSGs, indicating that $\mathrm{N}$-linked oligosaccharides of SP-A are not required for the interaction with MSGs.

$P$. carinii is a ubiquitos and oppotunistic pathogen, and a common cause of life-threatening pneumonia in imminodeficent patients. Patients with the acquired immunodeficiency syndrome (AIDS) who are infected with $P$. carinii have 2-3 fold elevations of SP-A in bronchoalveolar lavage [Sternberg, R.I., Whisett, J.A., Hull, W.M., and Baughman, R.P., (1995) J. Lab. Clin. Med. 125, 462-469]. SP-A has been shown to enhance adherence of $P$. carinii to alveolar macrophages, suggesting an opsonic role for the protein. The other hand increased SP-A may enhance pathogenicity by adhering to the $P$. carinii organism and interfering with host defenses. In this article it was shown that the first step of the binding of SP-A to $P$. carinii is mediated by lectin-carbohydrate interaction, however this interaction gives bnefits to us ? It still remains to be elucidated whether increased concentration of SP-A in blonchoalveolar lavage fluid is a cause or consequence of $P$. carinii infection, and whether SP-A is detrimental or beneficial to the pathogenesis of $P$. carinii pneumonia.

\section{Reported by Kojima, Kyoko}

Department of Chemistry, Faculty of Science Ochanomizu University, Otsuka, Tokyo 112, Japan

FAX: 81-3-5978-5344
が明らかになった。Asn214 Asp215 はCタイプレクチンに広 く保存されている Trp-Asn-Asp モチーフの中にあり、これらの 残基を置換した変異体は糖結合性を失うことから Trp-Asn-Asp モチーフの糖認識における重要性が確認された。SP-Aは一次配 列上に $\mathrm{N}$ 結合型糖鎖付加配列を2ヶ所持ち、SP-AのN 結合糖鎖 がウィルスにより認識されるという報告もあったが、本研究で SP-AのN結合型糖鎖付加部位を欠損した変異体でも MSGs との 結合には変化がみられなかったことからSP-Aの糖鎖はMSGs と の相互作用に必須でないことがわかった。

遍在性の日和見感染病原体であるニューモシスティスカリ 二は免疫不全患者に致死性の肺炎をひきおこす。カリ二肺炎を 併発した後天性免疫不全症候群 (AIDS) 患者の気管支炎肺胞液 中には SP-A の 2 3 倍の上昇がみとめられる [Sternberg, R.I., Whisett, J.A., Hull, W.M., and Baughman, R.P. (1995) J. Lab. Clin. Med. 125, 462-469]。SP-A はニューモシスティスカリニと気管 支マクロファージの接着を促進するためオプソニンとしての役 割が期待されるが、一方増加したSP-A はニューモシスティスカ リニと接着して病原性を促進、宿主防御を妨害するかもしれな い。SP-Aとニューモシスティスカリニの結合はレクチンと糖の 相互作用により成立することは明らかになったが、これは我々 に恩恵をもたらすのか否かは今のところわからない。そして肺 胞気管液におけるSP-Aの上昇はニューモシスティスカリニ感染 の原因となるのか、結果なのか、そして SP-Aはカリ二肺炎発症 を助けるのかじゃまをするのかが知りたいところである。

お茶の水女子大学 · 理学部 ·化学科

小島 京子 